\title{
Ethics Case Study: KPMG Faces Indictment Over Abusive Tax Shelters
}

\author{
Dennis Elam, Texas A \& M University Kingsville, USA
}

\begin{abstract}
This case examines the recent investigation and admission of guilt by KPMG for marketing abusive tax shelters. The concept of deferred prosecution is examined. The actions taken by KPMG to aggressively market the tax shelters are examined. Students are required to read both the civil complaint against KPMG as well as KPMG's official response to the Department of Justice inquiry. There is a comprehensive bibliography as well as website references for students to research the case. A detailed list of questions requires the students to analyze the ethical positions of all the parties involved. This case is directed to accounting students taking the required ethics course or an audit/assurance course and requires the use of an overhead projector that uses transparencies.
\end{abstract}

Keywords: Tax shelter, Criminal tax case, Tax fraud, KPMG, Criminal fines

Dubious tax shelters are no longer the province of shady, fly-by-night companies...they are now big business.

(US Attorney's Office for the southern District of New York, WSJ, 6/16/05)

These guys have got to wake up and get these things right.

(Victor Gerget, President of RateFinancials Inc., WSJ, 6/17/05)

Damage to a company's integrity can fell an organization if enough blows are sustained.

(Timothy Flynn, Chairman and CEO of KPMG, WSJ, 6/17/05)

\section{INTRODUCTION}

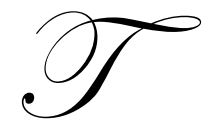

he June 16, 2005 front page of the Wall Street Journal made it clear that KPMG, the smallest of the four remaining international accounting firms, faced criminal indictment for its promotion of abusive tax shelters. The possibility of such an indictment has raised a debate at the Justice Department over at least two issues. First, should Justice risk whether such an indictment, not to mention a conviction, would implode the entire 18,000 member firm in an Arthur Andersen type scenario? Second, the Supreme Court recently reversed the conviction of Andersen. Ironically, this was far too late to save Andersen's 85,000 employees. The reversal is a reminder that such big cases can be lost with negative consequences to all involved. (WSJ, 6/16/05) Additionally, KPMG faces a civil class action suit by clients who bought tax shelters since deemed abusive by the IRS.

\section{FACTS OF THE CASE}

On June 16, 2005, KPMG issued a statement that faulted unidentified former partners for 'unlawful' conduct in marketing certain tax shelters from 1996-2002. (BW, 6/14/05) While the statement acknowledged 'full responsibility' for their actions, KPMG argues that it has methods in place to prevent future 'wrongdoing' and expects resolution that will involve appropriate sanctioning of the firm. KPMG is seeking what is termed a deferred prosecution from the Department of Justice. This is a practice that spares KPMG from being charged with a crime in exchange for paying a hefty fine, accepting a series of remedies, and cooperating with Justice in cases against individuals. (BW, 6/17/05) Observers have likened the bargaining process between KPMG and Justice to be 'like a game of volleyball.' The outcome for some 30 former KPMG partners and staff who have been 
terminated are not known. KPMG has some 1,600 partners world-wide. KPMG is estimated to have made as much as $\$ 124$ million from the sale of the shelters. It was once known as the 'go-to firm for tax shelters for wealthy individuals and corporations. (B/W, 6/17/05) Chart 1 lists some of the KPMG shelters that have been designated as 'abusive' by the IRS.

Chart 1: KPMG Shelters Deemed Abusive by the IRS

\begin{tabular}{|l|c|c|}
\hline Shelter & Abbreviation & KPMG Revenue \\
\hline Bond Linked Premium Structure & BLIPS & \$59-\$80 Million \\
\hline Foreign Leveraged Investment Program & FLIP & \$17 Million \\
\hline Offshore Portfolio Investment Strategy & OPIS & \$28-\$50 Million \\
\hline S-Corp. Charitable Contribution Strategy & SC2 & \$26-\$30 Million \\
\hline
\end{tabular}

Source, Senate Permanent Subcommittee on Investigations (WSJ, 6/16/05)

Allan D. Koltin, CEO of PDI Global, speculated that the government may want a multiple of the $\$ 124 \mathrm{M}$ as a fine. (BW 6/17/05)

A tax shelter is a scheme or device used to reduce or eliminate tax liability. Lawful tax shelters advance a legitimate endeavor. The IRS deems a shelter illegal if its only economic purpose is tax avoidance. KPMG and/or Brown and Wood issued opinion letters concerning the legality of the tax shelters. Such letters contained the verbiage 'the IRS is more likely than not' to approve the use of such shelters. By their own admission in the June 16, 2005 statement, the firm stated, "KPMG takes full responsibility for the unlawful conduct by former KPMG partners during that period, and we deeply regret that it occurred." (KPMG, 6/16/05) This would seem to be a full admission of guilt; the firm admits they knew or should have known the shelters would be labeled abusive and denied by the IRS.

According to the Senate Report, OPIS and BLIPS required the purchaser to establish a shell corporation, join a partnership, obtain a multi-million dollar loan, and engage in a series of complex financial transactions that had to be carried out in a certain order and in a certain way to realize tax benefits...the evidence collected by the subcommittee shows that KPMG was heavily involved in making sure the client transactions were completed properly. (Bernstein, p. 15)

OPIS and BLIPS were developed through KPMG's "Tax Innovation Center." It was the job of the Department of Practice and Professionalism (DPP) to approve such products. FLIP had an initial revenue goal of $\$ 4$ Million (M) and delivered \$11M. FLIP was later replaced by OPIS. Its goal was \$18M and it delivered \$28M. OPIS was replaced by BLIPS, targeted at $\$ 38 \mathrm{M}$ and delivering $\$ 52 \mathrm{M}$. (Bernstein, p. 16)

KPMG made the decision not to register OPIS as a tax shelter with the IRS. A 1998 memo determined that the penalties would be no greater than $\$ 14,000$ per $\$ 100,000$ in KPMG fees. In a September 1998 e-mail, KPMG Partner Mark Watson criticized OPIS as follows: "When you put the OPIS transaction together with this 'stealth' reporting approach, the whole thing stinks." Months later, he added, "I believe we are filing misleading, and perhaps false, returns by taking this reporting position." (Bernstein, p. 21)

Bernstein alleges that "the Brown and Wood opinions were a form opinion which was identical in all material respects to over 150 other tax opinions. On information and belief, Brown and Wood received $\$ 50,000$ for each tax opinion letters it provided. (Bernstein, p. 28)

KPMG designated partners to serve as National Development Champion and National Deployment Champion to direct the sales and marketing effort. KPMG operated a call center in Indiana staffed with telemarketers to cold-call prospective clients. A script was used in making the calls. KPMG utilized specialized software dubbed 'Opportunity Management System' to monitor the sales efforts. Other software was used to examine the existing client database to identify prospects. Notably the firm approached the client with the tax problem and solution. The clients were not seeking the firm. (Bernstein, p. 36) 
KPMG did not act alone in advising clients to enter these shelters. The parties involved in the civil suit include the following:

\section{DEFENDANTS}

KPMG www.kpmg.com KPMG actively marketed what the IRS has deemed to be abusive tax shelters from 19962002.

Sidley Austin Brown \& Wood (Sidley Austin) www.sidley.com/practice/practice.asp. According to their website, Sidley Austin Brown \& Wood has grown into a full service law firm with approximately 1,550 lawyers practicing on three continents.

Presidio Advisors LLC and Presidio Growth LLC are limited liability companies organized under the laws of the State of California and doing business in San Francisco, CA. Presidio served as advisers to plaintiffs and members of the Class.

Deutsche Bank www.db.com/ Deutsche Bank is a corporation organized under the laws of the Federal Republic of Germany and maintains its principal place of business in Frankfurt, Germany. Deutsche Bank AG and Deutsche Bank Securities are collectively referred to as Deutsche Bank.

Quellos Group LLC is a Delaware limited liability company with its principal place of business in Seattle, WA. Quello served as adviser to members of the class.

\section{PLAINTIFFS}

Thomas R. Becnel is a citizen of the State of Florida. He is Trustee of the Becnel Family Trust, an express intervivos trust. The Trust entered into an OPIS transaction. Jardine Ventrues LLDC is a limited liability company. Thomas R. Becnel, through Jardine Ventures LLC, entered into a BLIPS transaction. There are also other members of the class in similar situations. The class is represented by Bernstein Litowitz Berger \& Grossmann LLP www.blbglaw.com .

\section{RELEVANT DOCUMENTS}

It is a requirement of the case that the student download, print, read, and bring these documents to class. A copy of the civil complaint \#CV 2005-18 against KPMG can be viewed at www.blbglaw.com/complaints/ kpmg_complaint.pdf.

A copy of the KPMG statement June 16, 2005 can be viewed at http://www.us.kpmg.com/RutUS_prod/ Documents/8/KPMGStatement_DOJ_06_16_05.pdf.

\section{OTHER DEVELOPMENTS}

On January 20, 2005, KPMG announced it would hire US District Judge Sven Erik Holmes to oversee its legal affairs. He is Chief Judge of the US District Court for the Northern District of Oklahoma. He joined KPMG in March, 2005. Holmes has long standing ties to Washington where he was a former partner in the law firm of Williams and Connolly LLP.

On June 20, 2005, the Wall Street Journal in its lead editorial, questioned 'whether Justice really wants to repeat its Andersen blunder?' (WSJ, 6/20/05) The journal noted that Justice may indict the entire firm. However, most of the 30 partners, notified by Justice that they are targets of the investigation, have been terminated along with other senior executives. The editorial also notes that there might be a supervision problem at justice. Alberto Gonzales is the new Attorney General with little experience in criminal prosecution. David Kelley, leading the probe, is the acting US Attorney for the Southern District of New York. His boss, John Richter, is also in an acting capacity. Eileen O'Connor, the Assistant AG in the Tax Division has recused herself from the case. Deputy Attorney General James Comey is a lame duck having announced he is returning to private life. (WSJ, 6/20/05) 
An opinion piece ran in the WSJ June 27, 2005 by William Holstein, editor in chief of Chief Executive magazine. He notes 'that indicting entire companies, as with Arthur Andersen, is tantamount to a death sentence. (WSJ, 6/27/05)

\section{QUESTIONS FOR DISCUSSION}

1. KPMG has admitted to its guilt with its June 16, 2005 statement. Clearly, KPMG believes its statement and actions absolve the firm of past wrongdoing? Do you agree? Is there a 'line in the sand' beyond which an accounting firm cannot go and then repudiate its past? If so, where is KPMG in relation to that line?

2. Clearly, KPMG was delighted with the financial results of its National Tax Center as recently as 2001. What ethical questions are raised by such a rapid turnaround in their opinion of the shelters they crafted, endorsed, and sold? Can the present officers who were there during this time claim to have 'undertaken significant changes in its business practices' and still retain credibility?

3. Since the firm was a partnership, were the other 1,600 partners under some obligation to have internal controls to know what their partners were doing? Either way, that questions professional competence. Either the partners had controls and knew and ignored the findings, or controls did not exist, which brings the competence of these accountants into question. How do you think this affects the reputation of KPMG as an auditor of Fortune 500 companies?

4. KPMG is also facing various suits from clients. What do you think KPMG owes those clients? KPMG has fought those clients in court to avoid judgments. Can KPMG now claim to have 'undertaken significant changes in its business practices. Can those two positions be resolved? Is there an ethical conflict?

5. What course of action should the Department of Justice take - indict the entire firm, prosecute the 30 identified individuals and staff, proceed with the deferred prosecution, or some combination of these? What are the obligations of justice to KPMG, the 30 partners deemed guilty by KPMG, the clients, and to the accounting profession and their clients, in general?

6. The firm awarded those 30 partners with handsome bonuses and urged them to continue such activities. Now they have been cast out and criminalized by their former partners. They face potential jail sentences if found guilty. If you were one of those 30 partners, how would you view the ethics of your former partners now? What ethical constructs are being demonstrated by the surviving partners? Can Timothy Flynn, CEO of KPMG, square his opening statement in this case with the admission of criminal wrongdoing?

\section{AUTHOR INFORMATION}

Dennis Elam teaches Accounting Ethics as well as Intermediate and Advanced Cost Accounting at Texas A \& M San Antonio. He weaves academics with the 'real world of business' via his weblog at www.professorleam.typepad.com. He has taught at Texas State University and the University of Texas at the Permian Basin. Education innovation projects and other ethics cases authored by Professor Elam have been featured at national AAA meetings. He employs digital photography highlighting University activities on his blog. His and wife Christy are parents to three cats and the family Catahoula hound, Bentley.

\section{REFERENCES}

1. Bailey, Jeff, and Browning, Lynnley, "Move Leaves KPMG Open to Costly Claims," International Herald Tribune, New York Times, une 22, 2005, Finance, Pg. 15

2. "Bernstein Litowitz Berger \& Grossman LLP Provides Update," Business Wire, Inc. June 21, 2005

3. Bernstein Litowitz Berger \& Grossman LLP, Thomas R. Becnel et al vs KPMG et al, Case no CV 2005 18, 1/28/05, www.blbglaw.com/complaints/kpmg_complaint.pdf.

4. Browning, Lynnley, "OnE Family's Tale of Tax Shelter Gone Awry,” New York Times Business, July 8, 2005 , http://www.nytimes.com/2005/07/08/business/08shelter.html?ex=1121486400\&en=0dc77483e4e917db\&ei $=5070 \&$ emc $=$ eta 1

5. $\quad$ Editorial Page, "Gunning for KPMG, Does Justice Really Want to Repeat its Andersen Blunder?, The Wall Street Journal, June 20, 2005, P. A14 
6. Gullapalli, Diya, "KPMG's Glynn Takes the Helm At a Stormy Time," The Wall Street Journal, June 17, 2005, P. C1

7. Gullapalli, Diya, “Firms' Auditor Choices Dwindle,” The Wall Street Journal, June 21, 2005, P. C1

8. Johnson, Carrie and Masters, Brooke A.," KPMG Hires federal Judge; Firm Facing Investigation Civil Charges, The Washington Post, January 21, 2005, Financial Section P. E 01

9. Johnson, Carrie, "KPMG to Pay \$22.5 Million in Settlement, The Washington Post, April 20,2005 Financial E 01

10. KPMG, and Ledwith, George, "KPMG LLP Statement Regarding Department of Justice Matter, http://www.us.kpmg.com/RutUS_prod/Documents/8/KPMGStatement_DOJ_06_16_05.pdf

11. Morgenson, Gretchen, "KPMG Trying to Cut Deal on Liabilities, Filing States, The New York Times, June 23, 2005, Finance

12. Nag, Arindam, KPMG Apologizes Over Tax Shelters, Move Could Help Accounting Giant Steer Clear of an Indictment, Houston Chronicle, June 17, 2005, Business, Pg 2

13. Solomon, Deborah, and Gullapalli, Diya, "SEC Weighs a 'Big Three' World," The Wall Street Journal, June 22, 2005, P. C1

14. Solnik, Claude, "Big Four Accounting Firms Have Enough Work Without Smaller Clients," Dolan Media Newswires, Long Island Business News, march 18, 2005

15. TSCPA, More Good News than Bad for KPMG, Online 8/26/05 http://www.tscpa.org/welcome/AcctWeb/acctweb082605.asp\#1

16. Weber, Joseph, "How Big a Cloud is KPMG Under?" Business Week Online, McGraw-Hill, June 17, 2005

17. Wilke, John R., "KPMG Faces Being Indicted on Tax Shelters," The Wall Street Journal, June 16, 2005, Page 1

\section{WEBSITES}

1. $\quad$ KPMG www.kpmg.com

2. $\quad$ Sidley Austin Brown \& Wood (Sidley Austin) www.sidley.com/practice/practice.asp

3. Deutsche Bank www.db.com/

4. $\quad$ Bernstein Litowitz Berger \& Grossmann LLP www.blbglaw.com 


\section{TEACHING NOTES}

This case is worthy of attention in most accounting classes as an ethics exercise. There are at least two reasons for its inclusion.

First, it is the largest fine ever paid for criminal wrongdoing. Interestingly, there was no trial and KPMG paid a $\$ 456$ million non tax-deductible fine.

Under an agreement, KPMG LLP admitted criminal wrongdoing in creating fraudulent tax shelters to help wealthy clients dodge \$2.5 billion in taxes and agreed to pay \$456 million in penalties. KPMG LLP will not face criminal prosecution as long as it complies with the terms of its agreement with the government. On January 3, 2007, the criminal conspiracy charges against KPMG were dropped. ${ }^{[1]}$ However, Federal Attorney Michael J. Garcia stated that the charges could be reinstated if KPMG does not continue to submit to continued monitorship through September 2008. ${ }^{[2]}$

Second, an ethical person acts the same way regardless of circumstances. As this case progressed, the same parties assumed very different ethical stances. This challenges the students to examine the use of ethical theories. Were the participants 'shopping for an ethical basis' in the same way a client shops for a favorable accounting ruling?

Teaching Notes - follows the question numbers:

1. CPA firms are regarded by the public to be 'expert' regarding income tax matters. How can KPMG continue to claim expertise in tax matters while admitting they engaged in lawful misconduct? What does this say about the firm's future credibility? At what stage of Kohlberg's reasoning is the firm operating?

2. An ethical person does not change their ethical stance by putting the proverbial wet finger in the air to see which way the ethical wind is blowing. Yet, KPMG Partners have changed their stance. What brought about this revelation? Was their ethical transformation late in coming? Was it induced by the settlement offer? The students should be asked, "Should we take someone, who claims to have such a renewal of judgment, seriously?" While religions champion forgiveness, is there a line in the sand? Many criminals express remorse, but still go to jail. Are the KPMG partners any different?

Now take the opposite attack. In a capitalist society, markets respond to consumer needs and wants. When Congress passes such punitive tax laws that corporations seek tax havens, listing on foreign stock exchanges to avoid SARBOX, and after all tax avoidance is legal, has KPMG committed a crime or performed a service? The IRS only got upset at the amount of money it was not collecting. Was KPMG or Congress to blame for the 'customers' that sought help?

3. This question tests the students' knowledge of internal control. Ironically, all CPA firms now must express an opinion on a client's internal control. Did the apparent inability of KPMG to exercise its own internal control cast doubt on their competence?

4. The former clients of KPMG are now adversaries. Can KPMG change its horse in mid-stream? A famous expression says, "to dance with the one that brung you/ (to the dance, that is; do not change partners)". Ask the students how KPMG can now turn on its former clients who, after all, KPMG sought and promised to help? Again, is ANY ethical theory operative?

5. It appears that the Dept. of Justice did not want to implode another large accounting firm, a.k.a. Arthur Andersen. Was KPMG too big to fail? Ask the students what message this sends? What size is too big or too small (particularly important to the status of smaller firms like BDO, Block, and Grant Thornton). Would or should these firms get the same 'pay a fine and we will forget all about it' treatment?

6. In this instance, KPMG has turned on its own former partners. What do the students think of such behavior? Should the government be entrusted with the power to make such a thing happen? Is anyone, who attempts to save a client a tax bill, safe? 